Western New England University School of Law Digital Commons @ Western New England University School of Law

2018

\title{
Constitutional Law_-Do Black Lives Matter to the Constitution?
}

Bruce K. Miller

Western New England University School of Law, bmiller@law.wne.edu

Follow this and additional works at: https:// digitalcommons.law.wne.edu/facschol

Part of the Civil Rights and Discrimination Commons, and the Law and Race Commons

\section{Recommended Citation}

Bruce Miller, Constitutional Law—Do Black Lives Matter to the Constitutions?, 40 W. NEW ENG. L. REV. 459 (2018).

This Article is brought to you for free and open access by the Faculty Publications at Digital Commons @ Western New England University School of Law. It has been accepted for inclusion in Faculty Scholarship by an authorized administrator of Digital Commons @ Western New England University School of Law. For more information, please contact pnewcombe@law.wne.edu. 


\title{
CONSTITUTIONAL LAW - DO BLACK LIVES MATTER TO THE CONSTITUTION?
}

\author{
Bruce Miller*
}

INTRODUCTION: THE TwO CONSTITUTIONS

The question is, of course, a provocation. If read rhetorically; it lends itself (too) easily to equally categorical, opposing answers: Of course black lives don't matter to the Constitution's infamous three-fifths clause, ${ }^{1}$ its protection of property interests in escaped enslaved people, ${ }^{2}$ and its recognition of the states' power to control immigration of "such [p]ersons as any of the States now existing shall think proper to admit" until 1808. ${ }^{3}$ But that, of course, is the deeply compromised Constitution of the founders. Ours may be more accurately viewed as the Constitution of what has sometimes been called the Second Founding, the Constitution of the post-Civil War Amendments. ${ }^{4}$ This is the Constitution of Emancipation, and of Brown v. Board of Education, ${ }^{5}$ probably our most celebrated Supreme Court decision, and perhaps the only case that is indispensable to the rejoinder that black lives do indeed matter to

\footnotetext{
* Bruce Miller, Professor of Law at Western New England University School of Law. I'm grateful to the contributors to the Western New England Law Review symposium on the Black Lives Matter movement, and to the symposium's organizers and editors, Chelsea Donaldson and Karen Tiroletto, both WNEU Law '18, for generating the ideas that prompted this essay. I'm also indebted to the board and staff of the Western New England Law Review, 2017-18, and especially to Barbara Curatolo, Mayrose Gravalec-Pannone, and Emily McCoomb, also WNEU Law '18, for superb research, editorial, and technical help. Many thanks also to my able and patient faculty assistant, Sandy Marques.

1. U.S. CONST. art I, $\S 2$, cl. 3 .

2. U.S. CONST. art IV, $§ 2$, cl. 3.

3. U.S. CONST. art $1, \S 9$, cl. 1 .

4. For an instructive interpretation of the Civil War Amendments as constituting a Second Founding, see generally AKHIL REED AMAR, AMERICA'S CONSTITUTION: A BIOGRAPHY (2005); AKHIL REED AMAR, THE BILL OF RIGHTS: CREATION AND RECONSTRUCTION (1998). Professor Amar convincingly argues that the constitution can be consistent with basic principles of justice only because of the Second Founding. Id.

5. See generally Brown v. Bd. of Educ., 347 U.S. 483 (1954) (holding that segregated schools are unconstitutional).
} 
the Constitution.

The fruits of the Second Founding were slow to develop. The post-Civil War amendments did, of course, abolish the formal institution of slavery, ${ }^{6}$ secure birthright citizenship, ${ }^{7}$ grant (theoretical) black male suffrage, ${ }^{8}$ and provide a secure foundation for a set of crucial civil rights statutes enacted by the early Reconstruction Congress. ${ }^{9}$ But these statutes quickly fell into desuetude, to be revived by the Supreme Court only in the $1960 \mathrm{~s}^{10}$ when the Civil Rights Movement was at its apex. After the court's disposition of Civil Rights Cases ${ }^{11}$ in 1883, the Second Founding had little positive, and much negative, practical effect on the lives of African Americans until Charles Houston and his colleagues began to breathe life into the Fourteenth Amendment's Equal Protection Guarantee during the Great Depression. ${ }^{12}$ The nadir from which this effort began was aptly marked by Justice Holmes' (then sadly accurate) observation that the Equal Protection Clause is the last refuge of the desperate lawyer. ${ }^{13}$

Still, the Brown decision, however late its arrival, was no mean accomplishment. If it did not, in the end, make much of a permanent dent in the racial identifiability of America's public schools, ${ }^{14}$ it did crumble the formal legal foundations of Jim Crow. ${ }^{15}$

6. U.S. CONST. amend. XIII.

7. U.S. CONST. amend. XIV.

8. U.S. CONST. amend. XV

9. See 42 U.S.C. $\S \S 1981-83,1985(3)$ (2016); 18 U.S.C. $\$ \S 241-42$ (2016).

10. See generally Monroe v. Pape, 365 U.S. 167 (1961) (holding that the aforementioned statutes could be used in a cause of action against state officers violating constitutional rights).

11. See generally The Civil Rights Cases, 109 U.S. 3 (1883).

12. For a comprehensive examination of this effort, see RICHARD KLUGER, SIMPLE JUSTICE: THE HISTORY OF BROWN V. BOARD OF EDUCATION AND BLACK AMERICA's STRUGGLE FOR EQUALITY (1976); see also THE ROAD TO BROWN (California Newsreel 1990).

13. "[Equal Protection] is the usual last resort of constitutional arguments ...." Buck v. Bell, 274 U.S. 200, 208 (1927).

14. There are a number of good sources on the extent of desegregation and segregation of American public schools after 1980. See generally, especially, GARY ORFIELD, Dismantling DESEgREgATION: THE QUIET REVERSAL OF BROWN V. BOARD (1996); see also generally Jonathan Kozol, Savage Inequalities: Children in America's Schools, 26 CLEARINGHOUSE REV. 398 (1992); Joel K. Goldstein, Not Hearing History: A Critique of Chief Justice Roberts' Reinterpretation of Brown, 69 OHIO ST. L.J. 791 (2008).

15. Terrence J. Levin, Brown v. Board and the ISBA Board, 92 ILL. B.J. 116, 116 (2004) 
Probably more important, as Congressman John Lewis has pointed out, ${ }^{16}$ it inspired civil rights organizers like himself to believe that the law was with them, rather than their oppressors, and provided at least a prod, at best an inspiration, to the Congresses that enacted the Civil Rights Act of $1964^{17}$ and $1968^{18}$ and the Voting Rights Act of 1965. ${ }^{19}$ Finally, and perhaps most significantly for the persuasiveness of the Second Founding argument, the Supreme Court's announced commitment in Brown II to desegregation "with all deliberate speed" 20 prompted it to expand considerable institutional resources over nearly two decades in an effort to bring about this promised outcome. Through Green v. New Kent County, ${ }^{21}$ Alexander v. Holmes County Board of Education, ${ }^{22}$ and finally Swann V. Mecklenburg, ${ }^{23}$ the Court persisted in directing and approving measures aimed at dissolution of black schools and white schools in favor of a unitary regime of "just schools." 24 Although the Court eventually pulled back from this ambitious, unprecedented undertaking, ${ }^{25}$ and although America's public schools may again be nearly as racially identifiable as they were in $1954,{ }^{26}$ the example set by its effort to redeem Brown's aspiration suggested that the Constitution could be used to advance substantive visions of racial justice.

So, the Second Founding rejoinder to the original Constitution's corruption through its capture by slavery may not be summarily dismissed. But if the regime established by our fatally compromised charter was founded on white supremacy, it would be surprising if the lasting impact of that foundation could be eradicated by the adoption, eighty years later, of three amendments

\footnotetext{
16. See THE ROAD TO BROWN, supra note 12 .

17. Civil Rights Act of 1964, Pub. L. No. 88-352, 78 Stat. 241 (1964).

18. Civil Rights Act of 1968, Pub. L. No. 90-284, 82 Stat. 73 (1968).

19. Voting Rights Act of 1965, Pub. L. No. 89-110, 79 Stat. 437 (1965).

20. Brown v. Bd. of Educ. (Brown II), 349 U.S. 294, 301 (1955).

21. See generally Green v. Cty. School Bd., 391 U.S. 430 (1968).

22. See generally Alexander v. Holmes Cty. Bd. of Educ., 396 U.S. 19 (1969).

23. See generally Swann v. Charlotte-Mecklenburg Bd. of Educ., 402 U.S. 1

24. Green, 391 U.S. at 442.

25. See, e.g., Missouri v. Jenkins, 515 U.S. 70 (1995); Bd. of Educ. v. Dowell, 498 U.S. 237 (1991); Missouri v. Jenkins, 495 U.S. 33 (1990); Milliken v. Bradley, 418 U.S. 717 (1974).

26. Will Stancil, School Segregation is Not a Myth, ATLANTIC (Mar. 14, 2018), https://www.theatlantic.com/education/archive/2018/03/school-segregation-is-not-amyth/555614/ [https://perma.cc/ZK2B-A3DZ].
} (1971). 
which were themselves enforced only minimally for another eighty years, and inconsistently after that. The question posed by the title of this article is thus not intended rhetorically, in either direction. The extent to which black lives matter to the Constitution remains a matter of enduring controversy.

\section{DRED SCOTT}

Seventy years after the Constitutional Convention, the Supreme Court addressed the controversy directly. In Dred Scott $v$. Sandford, ${ }^{27}$ the Court was required to examine whether the Constitution's recognition of the legal legitimacy of slavery entailed an equivalent commitment to white supremacy. In an opinion whose candor probably depended on its author's assumption of widespread agreement by his audience, the Court's answer was a resounding yes.

Chief Justice Taney's statement of the question is succinct:

Can a negro, whose ancestors were imported into this country, and sold as slaves, become a member of the political community formed and brought into existence by the Constitution of the United States, and as such become entitled to all the rights, and privileges, and immunities, guarant[e]ed by that instrument to the citizen ${ }^{28}$

His response, pithy and unequivocal was,

We think they are not, and that they are not included, and were not intended to be included, under the word "citizens" in the Constitution, and can therefore claim none of the rights and privileges which that instrument provides for and secures to citizens of the United States. ${ }^{29}$

Thus are African Americans emphatically excluded from the polity established by the Constitution.

But it is the immediately following passage of Dred Scott, perhaps still shocking to at least some twenty-first century readers, that resonates with even greater salience:

The language of the Declaration of Independence is equally conclusive:

It begins by declaring that, "when in the course of human

27. Scott v. Sandford, 60 U.S. 393 (1857).

28. Id. at 403 .

29. Id. at 404 . 
events it becomes necessary for one people to dissolve the political bands which have connected them with another, and to assume among the powers of the earth the separate and equal station to which the laws of nature and nature's God entitle them, a decent respect for the opinions of mankind requires that they should declare the causes which impel them to the separation."

It then proceeds to say: "We hold these truths to be selfevident: that all men are created equal; that they are endowed by their Creator with certain unalienable rights; that among them is life, liberty, and the pursuit of happiness; that to secure these rights, Governments are instituted, deriving their just powers from the consent of the governed."

The general words above quoted would seem to embrace the whole human family, and if they were used in a similar instrument at this day would be so understood. But it is too clear for dispute, that the enslaved African race were not intended to be included, and formed no part of the people who framed and adopted this declaration; for if the language, as understood in that day, would embrace them, the conduct of the distinguished men who framed the Declaration of Independence would have been utterly and flagrantly inconsistent with the principles they asserted; and instead of the sympathy of mankind, to which they so confidently appealed, they would have deserved and received universal rebuke and reprobation. ${ }^{30}$

Not only, then, are black lives placed outside the Constitution, they are also, by virtue of their necessary exclusion from the more universalist ("All men are created equal") Declaration of Independence, cast out of the ranks of humanity itself. And the rationale for this exclusion - to save the founders from a hypocrisy that might undermine the greatness of their accomplishmentremains breathtaking, even if tragically accurate: the legitimacy of the (original) Constitution required our acceptance of its framers' unequivocal commitment to an ideology of white supremacy.

\section{PlesSy And the Re-Ratification OF White Supremacy}

The triumph of the Union in the Civil War, the Emancipation Proclamation, and the Constitutional Amendments that followed overruled the force of law of Dred Scott. But did these events, 
could they even, also upset the racist understanding of our Constitutional order that underlay Chief Justice Taney's opinion? As we know, the Supreme Court's pre-Brown treatment of the Equal Protection Guarantee suggests at its least that they did not. Plessy v. Ferguson, ${ }^{31}$ decided a generation after the Civil War and more than a century after the adoption of the original Constitution, illustrates the depth and tenacity of white supremacy's grip on the foundation of our basic law. The Supreme Court's decision in Plessy is now condemned for its approval of state mandated racial segregation of public accommodations and, through two generations of virtually unimpeded application of its rationale, to nearly every institution of American life. ${ }^{32}$ But the opinions in Plessy, majority and dissent alike, are also noteworthy for their explicit, matter-of-fact avowals of white supremacy.

Justice Brown's opinion for the Court does this in the guise of denying it:

We consider the underlying fallacy of the plaintiff's argument to consist in the assumption that the enforced separation of the two races stamps the colored race with a badge of inferiority. If this be so, it is not by reason of anything found in the act, but solely because the colored race chooses to put that construction upon it. $^{33}$

This absurd position depended on Justice Brown's ability to feign obliviousness to the questions raised by the enforced separation: Who commanded it? Upon whom was it enforced? And for what purpose was it enacted? This posture of indifference can be assumed only by someone for whom the answers to these questions are both personally and professionally irrelevant, to a judge who takes white control over American political life for granted.

Although Justice Harlan's Plessy dissent is justly celebrated for its defense of the formal legal equality of black and white citizens, its embrace of white supremacy is, sadly, equally emphatic. Justice Harlan's racism was directed most virulently against persons of Chinese descent:

There is a race so different from our own that we do not permit

31. See generally Plessy v. Ferguson, 163 U.S. 537 (1896).

32. See, e.g., KLUGER, supra note 12. (1954).

33. Plessy, 163 U.S. at 551, overruled by Brown v. Bd. of Educ., 347 U.S. 483 
those belonging to it to become citizens of the United States. Persons belonging to it are, with few exceptions, absolutely excluded from our country. I allude to the Chinese race. ${ }^{34}$

But Justice Harlan also left no doubt about the inevitable, perpetual superiority of whites over blacks:

The white race deems itself to be the dominant race in this country. And so it is, in prestige, in achievements, in education, in wealth, and in power. So, I doubt not, it will continue to be for all time, if it remains true to its great heritage, and holds fast to the principles of constitutional liberty. ${ }^{35}$

If anyone among the ruling elite of the United States at the turn of the twentieth century could be justly characterized as a champion of racial equality, it was Justice Harlan. As Professor Jim Gordon has shown, it is very likely he had an African American half-brother to whom he was deeply attached. ${ }^{36}$ And yet Justice Harlan was sufficiently embedded in the American culture's assumptions of white supremacy that he could openly rely on them without apparent awareness of contradiction.

\section{KOREMATSU'S ANALYTICAL SHADOW}

Though by then under challenge, ${ }^{37}$ Plessy still defined the dismal state of the Constitutional law of race when the Supreme Court decided Korematsu v. United States ${ }^{38}$ in 1944. Korematsu today has few defenders and was formally overruled, perhaps ironically, as part of the Supreme Court's June 2018 decision sustaining President Trump's ban on travel into the United States by non-citizens from a number of predominantly Muslim nations. ${ }^{39}$ But long before its formal abandonment by the Court, the decision to sustain the mandatory wartime evacuation of persons of Japanese descent, including American citizens, from the West Coast had come to be viewed with something approaching universal official regret. ${ }^{40}$ Nevertheless, Korematsu established the

34. Id. at 561 (Harlan, J., dissenting).

35. Id. at 559.

36. James W. Gordon, Did the First Justice Harlan Have a Black Brother?, 15 W. NEW ENG. L. REV. 159 (1993).

37. See, e.g., Missouri ex rel. Gaines v. Canada, 305 U.S. 337, 344-46 (1938).

38. See generally Korematsu v. United States, 323 U.S. 214 (1944).

39. See Trump v. Hawaii, 138 S. Ct. 2392, 2403-06 (June 26, 2018).

40. See generally PETER H. IRONS, JUSTICE AT LAW (1983); Eugene V. Rostow, The Japanese-Cases-A Disaster, 54 YALE L.J. 489 (1945). But see generally 
basic framework both for the Supreme Court's subsequent development of Equal Protection doctrine, and for the enduring role played by white supremacist assumptions in that development. That framework survives the decision's overruling.

We owe the adoption of strict scrutiny of racially discriminatory laws to Korematsu. As Justice Black's opinion for the Court put it:

[A]ll legal restrictions which curtail the civil rights of a single racial group are immediately suspect. That is not to say that all such restrictions are unconstitutional. It is to say that courts must subject them to the most rigid scrutiny. Pressing public necessity may sometimes justify the existence of such restrictions; racial antagonism never can. ${ }^{41}$

This instruction remains the premise from which the Supreme Court evaluates the constitutionality of measures challenged as racially discriminatory: They are suspect (likely to be unconstitutional), subject to strict scrutiny (entitled to no judicial deference to the legislative or executive rationale for their legitimate goal), and justified only by pressing public necessity (permitted only if they are necessary to the pursuit of a compelling public interest).

The Korematsu majority opinion adhered to this exacting standard in name only, given the opinion's unquestioning, even credulous, acquiescence in the judgment of military authority as to the fate of civilians on American soil:

[E]xclusion of those of Japanese origin was deemed necessary because of the presence of an unascertained number of disloyal members of the group, most of whom we have no doubt were loyal to this country. It was because we could not reject the finding of the military authorities that it was impossible to bring about an immediate segregation of the disloyal from the loyal that we sustained the validity of the curfew order as applying to the whole group. In the instant case, temporary exclusion of the entire group was rested by the military on the same ground. The judgment that exclusion of the whole group was for the same reason a military imperative answers the contention that the exclusion was in the nature of group punishment based on

Richard Posner, LAW, Pragmatism, ANd DEMOCRACY 294 (2005).

41. Korematsu, 323 U.S. at 216. 
antagonism to those of Japanese origin. ${ }^{42}$

But Korematsu merits our attention today for more than just its simultaneous adoption and betrayal of the principle of strict scrutiny. The decision is also important for its treatment of three related questions that lie at the root of the intersection of the Second Founders' commitment to racial equality, and the original Constitution's reliance on white supremacy. These questions are, first, how do we know that a law or policy is racially discriminatory? Does the answer depend on the measure's form, that is, on whether it explicitly classifies people on the basis of their ascribed racial identity? Or does it turn more on our understanding of why it was adopted and what impact its enforcement has? The second question, growing out of the first, is whether we should seek to understand and evaluate the extent to which a challenged measure's adoption was influenced by white supremacist ideology, explicitly or tacitly. And the third and perhaps most important of these questions, is why is it that the post-Civil War Amendments, in particular the Fourteenth Amendment, placed the force of our constitutional law behind the principle of racial equality? Were these amendments primarily directed to erasing racial animus, particularly animus by whites toward African Americans? Or were they aimed at remedying the race-based subordination of African Americans on which slavery was founded?

The Korematsu majority opinion provides answers to all three of these questions. From an anti-white supremacist perspective, these answers are a mixed bag-perhaps modestly encouraging with respect to the first, much less so for the second and third.

\section{A. Korematsu and Formalism}

First, the Korematsu majority opinion's understanding of the policy of Japanese evacuation was only partially based on the policy's linguistic form. President Roosevelt's executive order authorizing civilian exclusion for military reasons did not, by its language, single out persons of Japanese ethnicity or ancestry as its targets. Instead, it provided that military commanders on the West Coast could designate areas "from which any or all persons may be excluded, and with respect to which, the right of any person to

42. Id. at 218-19. 
enter, remain in, or leave shall be subject to whatever restrictions [a Commander] may impose in his discretion." 43 And the statute under which Fred Korematsu was convicted, criminalized, again without reference to race or national origin-violation of military exclusion orders. ${ }^{44}$ To be sure, the military order Korematsu violated did single out persons of Japanese ancestry for exclusion..$^{45}$ But it did not apply to all such persons (Japanese people residing away from the West Coast were largely exempt). ${ }^{46}$ Of the approximately 260,000 persons of Japanese origin residing in the United States at the time of the Executive Order, something more than one hundred thousand were subjected to military evacuation. ${ }^{47}$ And at least some (though far fewer) persons of German and Italian ancestry were subjected to similar exclusionary measures. ${ }^{48}$

Korematsu is conventionally understood as an example of facial, or de jure discrimination against a racial and national origin minority-and so it is, in part. But the broader context of the military exclusion orders also shows elements of a facially neutral law or policy that was applied with a racially discriminatory purpose and effect. As early as 1886 in Yick Wo v. Hopkins ${ }^{49}$ the Supreme Court condemned the official direction of a formally neutral policy against a racial minority, there persons of Chinese ethnicity.

[T]he facts shown establish an administration directed so exclusively against a particular class of persons as to warrant and require the conclusion that, whatever may have been the intent of the ordinances as adopted, they are applied by the public

43. Exec. Order No. 9066, 7 Fed. Reg. 1407 (Feb. 25, 1942).

44. 18 U.S.C. $\$ 9(2016)$.

45. Civilian Exclusion Order, No. 34, 7 Fed. Reg. 3967 (May 28, 1942); see IRONS, supra note 40.

46. Exec. Order No. 90667 Fed. Reg. 1407 (Feb. 25, 1942); Civilian Exclusion Order No. 34, 7 Fed. Reg. 3967 (May 28, 1942); see also JACOBUS TENBROEK ET AL., PREJUDICE, WAR AND THE CONSTITUTION: CAUSES AND CONSEQUENCES OF THE EVACUATION OF THE JAPANESE AMERICANS IN WORLD WAR II (5th prtg. 1954).

47. See Dennis M. Ogawa \& Evarts C. Fox, Japanese Internment and Relocation: The Hawaii Experience, in JAPANESE AMERICANS: FROM RELOCATION TO REDRESS 135 (Roger Daniels et al. eds., 1991).

48. See World War II Enemy Alien Control Program Overview, NAT'L ARCHIVES (Sept. 19, 2017), https://www.archives.gov/research/immigration/enemyaliens-overview.html [https://perma.cc/39CR-C5NZ].

49. See generally Yick Wo v. Hopkins, 118 U.S. 356 (1886). See also generally Griffin v. Cty. Sch. Bd., 377 U.S. 218 (1964); Gomillion v. Lightfoot, 364 U.S. 339 (1960). 
authorities charged with their administration, and thus representing the state itself, with a mind so unequal and oppressive as to amount to a practical denial... of [Equal Protection].... Though the law itself be fair on its face and impartial in appearance, yet, if it is applied and administered by public authority with an evil eye and an unequal hand, so as practically to make unjust and illegal discriminations between persons in similar circumstances, material to their rights, the denial of equal justice is still within the prohibition of the [C]onstitution. ${ }^{50}$

The evacuation of people of Japanese origin from the West Coast was, in some significant respects, also rooted in the sort of non-formal race discrimination condemned in Yick Wo. Notwithstanding this ambiguity, Justice Black's opinion for the Court in Korematsu quite properly treated the evacuation as racially discriminatory, and thus (theoretically) subject to the highest level of Equal Protection scrutiny. Chief Justice Roberts' recent statement overruling Korematsu in Trump v. Hawaii has now decisively resolved the ambiguity in favor of a purely formal view of the legal basis for the evacuation. ${ }^{51}$ Still, the question remains whether the Japanese evacuation would (or should) have eluded strict scrutiny if General DeWitt had only refrained from naming his targets openly.

\section{B. Korematsu and Societal Discrimination}

With respect to the second question, the Korematsu opinion was resolute in its insistence that the racist assumptions which lay at the heart of the exclusion were irrelevant to its constitutionality. The reason for this willful (or, more likely, pretended) blindness was the military necessity that served as the executive order's justification. Per Justice Black:

To cast this case into outlines of racial prejudice, without reference to the real military dangers which were presented, merely confuses the issue. Korematsu was not excluded from the Military Area because of hostility to him or his race. [Korematsu] was excluded because we are at war with the Japanese Empire .... 52

50. Yick Wo, 118 U.S. at $373-74$.

51. Trump v. Hawaii, 138 S. Ct. 2392, 2423 (June 26, 2018).

52. Korematsu v. United States, 323 U.S. 214, 223 (1944) (emphasis omitted). 
Thus, the mere statement of a relationship between a concededly suspect classification and the (also conceded) imperative of winning the war, warranted complete disregard for the Exclusion Order's roots in long standing, deep seated antiJapanese prejudice. Justice Murphy's unchallenged observation, in dissent, that the "exclusion was the result in good measure of this erroneous assumption of racial guilt," 53 that it rested "mainly upon questionable racial and sociological grounds" and "an accumulation of much of the misinformation, half-truths and insinuations that for years have been directed against Japanese Americans by people with racial and economic prejudices" ${ }^{\prime 4}$ could simply be ignored.

\section{Korematsu and Racial Animus}

Finally, Korematsu grounded the presumptive constitutional prohibition against racial discrimination in a public commitment to denying the force of law to measures based on "racial antagonism." 55 To thwart racial antagonism, or animus, as it is often called today, is indeed a worthy public goal. But if the purpose of the post-Civil War Amendment was to provide a new, non-racist basis for our constitutional order, to eradicate the white supremacist foundation of the original charter, preventing antagonism does not quite capture it. The point of the prohibition against racial discrimination is less to ameliorate strife or ill-feeling among racial groups than to end the subordination of non-whites, particularly formerly enslaved African Americans, by white political majorities. ${ }^{56}$

Moreover, the prevention of racial animus, once it is identified as the goal of the equal protection guarantee, is too easily satisfied by an arguably legitimate alternative explanation for a contested public law or policy. In Korematsu, the military judgment that "exclusion of the whole group was... a military imperative answers the contention that the exclusion was in the nature of group punishment based on antagonism to those of Japanese

53. Id. at 235 (Murphy, J., dissenting).

54. Id. at 236, 239.

55. Id. at 216 .

56. For an insightful discussion of the anti-subordination purposes of the postCivil War Amendments, particularly the Fourteenth Amendment, see generally Reva B. Siegel, Equality Talk: Antisubordination and Anticlassification Values in Constitutional Struggles Over Brown, 117 HARV. L. REV. 1470 (2004). 
origin. ${ }^{" 57}$ Perhaps. But if it does, the constitutional door is open to the use of minority racial status as a proxy for the pursuit of other ostensibly legitimate, racially neutral public goals. As long as a measure is not racially antagonistic, the fact that it employs race as a proxy becomes unobjectionable, and, completing the circle, the proxy itself proves the absence of antagonism.

By contrast, from an anti-subordination perspective, the fact that the Korematsu exclusion order was adopted as a military measure would not so easily justify the visitation of nearly all its costs on a single historically and contemporaneously oppressed racial minority. In a white supremacist culture, a racial minority need not be hated in order to be subordinated.

\section{KOREMATSU'S LASTING IMPACT}

Despite the case's outcome, and its relatively late arrival in our constitutional history (more than a century and a half after ratification of the original Constitution, three quarters of a century after the adoption of the Fourteenth Amendment and half a century after Plessy), Korematsu's adoption of the strict scrutiny standard showed the promise of the Second Founding's redemptive account of the Constitution. But much of the Supreme Court's subsequent application of the standard has undermined that promise. Unfortunately, even before Trump v. Hawaii, the Court had largely disregarded Korematsu's non-formalist elements. By contrast, it has fully embraced both its indifference to the role of societal discrimination in the adoption of discriminatory measures and its elevation of antagonism over subordination as the principal evil targeted by the Constitution's prohibition against racial discrimination.

\section{A. The Triumph of Formalism}

The legacy of Brown $v$. Board of Education ${ }^{58}$ shows the contemporary importance of a formal, written racial classification to the decision whether a public law or policy implicates Equal Protection concerns. The system of de jure school segregation held unconstitutional in Brown was given formal effect by statutes which explicitly required segregation of public school students by race. But segregation was, of course, much more than a formal system of

57. Korematsu, 323 U.S. at 219.

58. See generally Brown v. Bd. of Educ., 347 U.S. 483 (1954). 
law; it was a way of life founded on white supremacy. As Professor Charles Black, himself a son of the segregated South, famously observed:

[The] [p]urpose and impact of segregation in southern regional culture were matters of common notoriety, matters not so much for judicial notice as for the background knowledge of educated men [sic] white live in the world .... [I]f a whole race of people finds itself confined within a system which is set up and continued for the very purpose of keeping it in an inferior station, and if the question is then solemnly propounded whether such a race is being treated "equally," I think we ought to exercise one of the sovereign prerogatives of philosophers-that of laughter. ${ }^{59}$

For the better part of two decades, the Supreme Court recognized that segregation was less a formal system of racial classification than a political regime of racial domination and subordination. The Court both rejected formally equal measures and mandated race-consciousness ones in its effort to uproot this regime. ${ }^{60}$

The Supreme Court's commitment to this effort eventually ebbed. And as it did, the Court began to address the constitutionality of measures adopted by public authorities for the openly avowed purpose of remedying the consequences of our country's history of racial subordination. Not surprisingly, these measures often made explicit, formal reference to race. ${ }^{61}$ These remedial laws have met with mixed fates-some sustained ${ }^{62}$ some struck down. ${ }^{63}$ What is significant, for purposes of assessing the results of post-Civil War Amendments' commitment to racial

59. Charles L. Black, Jr., The Lawfulness of the Segregation Decisions, 69 YALE L.J. 421, 424 (1960); see also KLUGER, supra note 12.

60. See generally Swann v. Charlotte-Mecklenburg Bd. of Educ., 402 U.S. 1 (1971); Alexander v. Holmes Cty. Bd. of Educ., 396 U.S. 19 (1969); Green v. Cty. School Bd., 391 U.S. 430 (1968); Griffin v. Cty. Sch. Bd., 377 U.S. 218 (1964).

61. See, e.g., Fisher v. Univ. of Texas at Austin, 136 S. Ct. 2198 (2016); Parents Involved in Cmty. Schs. v. Seattle Sch. Dist., 551 U.S. 701 (2007); Gratz v. Bollinger, 539 U.S. 244 (2003); Adarand Constr., Inc. v. Pena, 515 U.S. 200 (1995); Richmond v. J.A. Croson Co., 488 U.S. 469 (1989); Wygant v. Jackson Bd. of Educ., 476 U.S. 267 (1986); Fullilove v. Klutznick, 448 U.S. 448 (1980); Regents of the Univ. of Cal. v. Bakke, 438 U.S. 265 (1978).

62. See, e.g., Fisher, 132 S. Ct. at 2198; Fullilove, 448 U.S. at 448.

63. See Parents Involved, 551 U.S. at 701; Bollinger, 539 U.S. at 244; Pena, 515 U.S. at 200; J.A. Corson, 488 U.S. at 469; Wygant, 476 U.S. at 267; Fullilove, 448 U.S. at 448; Bakke, 438 U.S. at 265. 
equality, is that all of them, from Regents of the University of California v. Bakke ${ }^{64}$ on, have been evaluated under the same standard of strict judicial scrutiny adopted in Korematsu. The stated reason for the Court's skeptical treatment of these remedial measures was their use of race as a facial classifying device. ${ }^{65}$ The aims of the measures and the effects of their implementation were irrelevant to the Court's assignment of the proper standard of review. Their failure to be formally neutral was all that mattered. ${ }^{66}$ In this sense, all racial classifications were created equal, whether their goal was to entrench or to attack racial subordination.

By 2007, this emphasis on form had produced absurd results. In a case challenging measures adopted by two cities-one northern and never segregated by law, the other in the upper south and once within the ambit of Brown's desegregation commandthe Court held that efforts to achieve the racial integration of public schools were unconstitutional because they explicitly took the racial background of students into account in assigning them to particular schools. ${ }^{67}$

Brown's command to public authorities was thus revealed to be almost fetishistically formal: Do not classify on the basis of race, even if your goal is to bring about the unitary, non-racially identifiable schools we once championed. As Chief Justice Roberts put it, as though it were a bon mot, "[t]he way to stop discrimination on the basis of race is to stop discriminating on the basis of race." 68

The formalization of the anti-discrimination principle also meant that the Supreme Court became largely indifferent to laws and policies which harm racial minorities, so long as the harm was inflicted without using an explicit racial classification. Beginning with Washington v. Davis ${ }^{69}$ in 1976, formal racial neutrality was sufficient to insulate these measures from meaningful constitutional scrutiny unless a challenger could demonstrate that the measure's adoption was prompted by a specific purpose to injure people on the basis of their race: "We have not held that a law, neutral on its

64. See generally Korematsu v. United States, 323 U.S. 214 (1944).

65. See, e.g., Bakke, 438 U.S. at 291 ("Racial and ethnic distinctions of any sort are inherently suspect and thus call for the most exacting judicial examination.").

66. Id.

67. Parents Involved, 551 U.S. at 745-48.

68. Id. at 748 .

69. See generally Washington v. Davis, 426 U.S. 229 (1976). 
face and serving ends otherwise within the power of government to pursue, is invalid...simply because it may affect a greater proportion of one race than of another."70 Ironically, Justice White's opinion for the Court in Davis justified this indifference to disparate racial impact by recalling the initial, anti-formalist impulse of Brown:

The school desegregation cases have also adhered to the basic equal protection principle that the invidious quality of a law claimed to be racially discriminatory must ultimately be traced to a racially discriminatory purpose.... "The differentiating factor between de jure segregation and so-called de facto segregation . . . is [p]urpose or [i]ntent to segregate." $" 11$

But if Brown is to be seen as a sword against white supremacy, Justice White's italicization is incomplete. The evil of segregation was indeed white lawmakers' invidious purpose or intent to segregate black people. But for Davis' formally minded court, an invidious purpose is evinced only if it is either explicitly avowed or effected through a formal racial classification. So long as lawmakers discreetly eschew facial discrimination, virtually any racial outcome is beyond Constitutional concern. Professor Black's admonition that racial subordination is more than a matter of form has apparently fallen from judicial memory. ${ }^{72}$

Relying on the Davis doctrine, the Court has sustained zoning policies designed to prevent the construction of low income housing in largely white suburbs; ${ }^{73}$ the enforcement of capital punishment in the face of an overwhelming statistical demonstration of adverse impact on African Americans $;{ }^{74}$ and more recently, Attorney General John Ashcroft's singling out of Arab and Muslim immigrants for inhumane treatment in the aftermath of the September 11, 2001 attacks. $^{75}$ The Court summarized its approach in a decision rejecting a challenge to a system of preference for veterans in public jobs as discriminatory

\footnotetext{
70. Id. at 242 .

71. Id. at 240 (quoting Keyes v. Sch. Dist. No. 1, 413 U.S. 189, 205 (1973)) (second alteration in original).

72. Charles L. Black, Jr., The Lawfulness of the Segregation Decisions, 69 YALE L.J. 421, 424 (1960).

73. Vill. of Arlington Heights v. Metro. Hous. Dev. Corp., 429 U.S. 252, 269-71

74. McCleskey v. Kemp, 481 U.S. 279, 319-20 (1987).

75. Ashcroft v. Iqbal, 556 U.S. 662, 682-83 (2009).
} (1977) 
against women. Its opinion emphasized that in order to be unconstitutional, a measure challenged because of its adverse disparate effects on women or racial minorities must be shown to have been adopted "because of, not merely in spite of" these effects,${ }^{76}$ that is, with a specific intent to inflict harm on the basis of race or sex.

\section{B. The Indifference to Societal Discrimination}

A corollary of the Supreme Court's formalization of constitutional race discrimination law has been its unwillingness to recognize the relevance of historic and current societal discrimination against racial minorities, i.e. the enduring impact of white supremacy on public policies and laws. This rejection is expressed most directly in the Court's decisions, mentioned above, evaluating the constitutional permissibility of racial measures which favor members of subordinated minority racial groups, especially African Americans. Since the 1970s, the Court has, sometimes narrowly, but uniformly, precluded the consideration of evidence of societal discrimination as a justification for such measures. ${ }^{77}$ Instead, the Court has limited government entities' power to enact measures aimed at redressing discrimination against racial minorities to those measures targeted directly at the enacting authority's own discriminatory actions. ${ }^{78}$ The harm of societal discrimination, by contrast, was characterized as "an amorphous concept of injury that may be ageless in its reach into the past."79 By so blithely dismissing our heritage of white supremacy, the Court has not only ignored Faulkner's reminder that "the past is never dead; it's not even past" ${ }^{80}$, it has also effectively crippled collective efforts directly to dismantle that heritage. Racially remedial measures can, as a consequence, be defended only on the ground that they advance a genuinely amorphous value known as "diversity." 81 The pursuit of diverse perspectives in educational

76. Id. at 676-77 (quoting Pers. Adm'r of Mass. v. Feeney, 442 U.S. 256, 279 (1979)).

77. See, e.g., Richmond v. J.A. Croson Co., 488 U.S. 469, 493-99 (1989); Wygant v. Jackson Bd. of Educ., 476 U.S. 267, 274-77 (1986); Regents of the Univ. of Cal. v. Bakke, 438 U.S. 265 (1978).

78. Richmond, 488 U.S. at 469; Wygant, 476 U.S. at 267. See generally Bakke, 438 U.S. 265.

79. Bakke, 438 U.S. at 307.

80. WILLIAM FAULKNER, REQUIEM FOR A NUN (1951).

81. See generally Fisher v. Univ. of Texas, 136 S. Ct. 2198 (2016); Gratz v. 
and workplace settings may well confer significant benefits on American society as a whole, even if the immediate beneficiaries of the life experience brought to these settings by non-whites are their white majority colleagues. But, for this same reason, "diversity" also runs the risk of at least appearing to patronize those whose identities are thought to confer it. And regardless of its worthiness as a social goal, diversity is, by itself, at best only indirectly related to the redemptive purpose of the Second Founding: to transform the political regime of racial subordination which established, and was then enforced by, the original Constitution.

Indifference to the impact of unbroken societal discrimination against African Americans and other racial minorities has also marked the Supreme Court's lenient treatment, also discussed above, of formally non-racist laws and policies which are challenged because of their alleged purpose and impact. The 1987 case, McCleskey v. Kemp, ${ }^{82}$ illustrates the depth of the Court's apathy. McCleskey presented a challenge to Georgia's regime of capital punishment as discriminatory against African Americans. The challenge was supported by a study, assumed by the Justices to be valid, showing, first, that defendants charged with killing whites were 4.3 times more likely to receive a death sentence as defendants charged with killing blacks, and second, that black defendants charged with killing white victims had by far the greatest likelihood of receiving a death sentence. ${ }^{83}$

In a 5-4 decision, the Supreme Court found the study to be irrelevant. In order to make out a claim of unconstitutional racial discrimination, a black defendant would have to prove either that the judge or jury in his own case discriminated against him or that the Georgia legislature, even assuming full knowledge of how it operated, maintained its death penalty statute for the specific purpose of harming blacks. ${ }^{84}$ "[I]ntent as awareness of consequences" $" 85$ meant nothing. Even "intent as volition" ${ }^{" 16}$ was insufficient to engage the concerns of the Equal Protection Guarantee. No matter the impact, and notwithstanding Georgia's Confederate and Jim Crow history, its regime of capital

Bollinger, 539 U.S. 244 (2003); Bakke, 438 U.S. 265.

82. See generally McCleskey v. Kemp, 481 U.S. 279 (1987).

83. Id. at 287.

84. Id. at 298 .

85. Id.

86. Id. 
punishment was constitutionally suspect only if it could be shown to have been enforced for reasons of otherwise purposeless racial hatred.

This willful blindness to the historical and social context of capital punishment is accompanied by an equal obliviousness to what the social sciences have taught us about how racial prejudice structures citizens' background beliefs and assumptions in a society built on white supremacy. As Professor Charles Lawrence pointed out more than a generation ago ${ }^{87}$ we should not find it surprising that our common history has led us to associate racial minorities, especially African Americans, with danger, threats to social order, less than full humanity, and even white fear of revolutionary revenge. The resulting unconscious prejudice ${ }^{88}$ shapes the perspectives of everyone, not just whites, poisons our common discourse, and corrupts our politics. To ignore the likely effect of this unconscious prejudice on our policy choices is to disable us from even considering whether these choices may reinforce racial subordination.

Justice Brennan's dissenting opinion in McCleskey pointed to an irony in the majority's rejection of statistics showing the racially uneven enforcement of Georgia's death penalty statute:

The Court ... states that its unwillingness to regard petitioner's evidence as sufficient is based in part on the fear that recognition of McCleskey's claim would open the door to widespread challenges to all aspects of criminal sentencing. Taken on its face, such a statement seems to suggest a fear of too much justice. ${ }^{89}$

Justice Brennan's observation can, of course, be extended far beyond the domain of the criminal justice system. If statistical evidence of their impact on racial minorities provided a lens for scrutinizing their constitutionality, it is possible that many of our laws and policies would be vulnerable. Perhaps that is too much justice. Perhaps, more modestly, this kind of searching scrutiny is beyond the remedial capacity of our courts. Either way, the indifference to racial impact exemplified by McCleskey profoundly

87. See generally Charles R. Lawrence III, The Id., the Ego, and Equal Protection: Reckoning with Unconscious Racism, 39 STAN. L. REV. 317 (1987).

88. Id. at 349.

89. McCleskey, 481 U.S. at 339 (Brennan, J., dissenting) (internal citation omitted). 
limits the racially redemptive potential of the Fourteenth Amendment.

The demand for evidence of official intention to inflict harm on racial minorities has prompted a (usually futile) search for smoking gun evidence of racism-e.g., overt statements of racial prejudice or stereotyping by decision makers. In a legal regime which condemns such statements, but little else, as constitutionally impermissible, a competently advised legislative body or public executive will almost never utter them. Almost never, but not absolutely never. Our current President, for example, notoriously jeopardized the ultimate judicial vindication of his proposed bans on entry into the United States of nationals of particular countries by a series of widely disseminated public statements taken to be expressions of religious bigotry. ${ }^{90}$ During the April 25, 2018 Supreme Court oral argument in the litigation challenging the most recent of the travel bans, Chief Justice Roberts asked the challengers' lawyer whether the President could immunize his orders from constitutional attack by disclaiming these statements:

"If tomorrow he issues a proclamation saying he's disavowing all these statements, then the next day he can re-enter this [order]?"91

Perhaps not surprisingly, given the near indispensability of smoking gun evidence to make out a claim of discriminatory purpose, the lawyer's response was, simply and directly, "yes."

But it may be fair to ask how necessary, in the end, Mr. Trump's odious statements were to making the case that the travel ban was unconstitutional. We know now that a narrow majority of the Supreme Court found the remarks to be insufficient to outweigh what it saw as the final ban's permissibility as an exercise

90. Josh Gerstein, Sparks Fly over Trump Tweets at Travel Ban Court Arguments, POLITICO (Dec. 8, 2017), https://www.politico.com/story/2017/12/08/ trump-travel-ban-4th-circuit-hearing-287242 [https://perma.cc/G4YU-N359].

91. Adam Liptak, Supreme Court Arguments on Trump's Travel Ban: Key Moments, N.Y. TIMES (Apr. 25, 2018), https://www.nytimes.com/2018/04/25/us/politics/ supreme-court-arguments-trumps-travel-ban-annotated-excerpts.html; see also Adam Liptak \& Michael D. Shear, Key Justices Seem Skeptical of Challenge to Trump's Travel Ban, N.Y. TIMES (Apr. 25, 2018), https://www.nytimes.com/2018/04/25/us/ politics/trump-travel-ban-supreme-court.html.

92. Adam Liptak, Supreme Court Arguments on Trump's Travel Ban: Key Moments, N.Y. TIMES (Apr. 25, 2018), https://www.nytimes.com/2018/04/25/us/politics/ supreme-court-arguments-trumps-travel-ban-annotated-excerpts.html. 
of executive power. ${ }^{93}$ But suppose Mr. Trump had made no inflammatory statements. If the bans had otherwise been adopted in the same form, and by the time sequence, same process, with the same professed goals, and with the same application and impact, would (or at least should) the arguments against their constitutionality become insubstantial? Would not (or should not) the present atmosphere of fear and suspicion of Muslim immigrants, combined with the halting and uneven application and effects of the final travel ban, be enough to suggest strongly that it discriminates on the basis of religion? Understandably, and perhaps strategically sensible as it was, counsel's oral argument concession may have surrendered the strongest grounds for invalidating it.

Nor should smoking gun evidence of discriminatory intent be sufficient to demonstrate that a policy is discriminatory. If it is, the search to tease it out runs the risk of jeopardizing the enforcement of entirely valid laws and policies because of an alleged taint resulting from official expression of an impermissible motive. Unless an invidious purpose is actually realized through a law of policy, the (bad) motives of government actors ought not to matter. As Professor Deborah Hellman has argued in her illuminating account of the moral basis of anti-discrimination law,

[I]t makes sense to be concerned with how people are treated rather than passing... judgment on the agents who draw the distinctions.... A bad intent ... does not insure that the action itself is morally wrong. If the action itself-described without reference to the intentions it springs from-is permissible, the intention to demean ... will not change its moral valence. ${ }^{94}$

The Supreme Court's recent decision in Masterpiece Cakeshop, Ltd. v. Colorado Civil Rights Commission ${ }^{95}$ aptly illustrates the problem described by Professor Hellman. In Masterpiece Cakeshop, the Court reversed Colorado's enforcement of its statute prohibiting discrimination by businesses on the basis of a customer's sexual orientation against a baker who refused to provide a wedding cake to a same-sex couple. ${ }^{96}$ The baker argued that his decision not to provide the cake was based on

93. Trump v. Hawaii, 138 S. Ct. 2392, 2420-23 (June 26, 2018).

94. DEBORAH HELLMAN, WHEN IS DISCRIMINATION WRONG? 167 (2008).

95. See generally Masterpiece Cakeshop, Ltd. v. Colo. Civil Rights Comm'n, 138 S. Ct. 1719 (June 26, 2018).

96. Id. at 1720 . 
his religious opposition to same-sex marriage and was therefore protected by his constitutional right to the free exercise of religion.

After an investigation by state agency staff, an administrative law judge, the seven-member Colorado Civil Rights Commission, and the Colorado Court of Appeals unanimously rejected the baker's defense. ${ }^{97}$ They found, in an unexceptional application of settled federal constitutional law, that the free exercise clause "does not relieve an individual of the obligation to comply with a valid and neutral law of general applicability." 98 The Supreme Court's decision to set aside Colorado's judgment did not purport to question or qualify this principle. Instead, Justice Kennedy's opinion for the court pointed to the following, on the record, remarks by two of the state's seven civil rights commissioners:

Commissioner \#1:

"[A businessman] can believe 'what he wants to believe' but cannot act on his religious beliefs 'if he decides to do business in the state." $" 99$

And

"'[I]f a businessman wants to do business in the state and he's got an issue with the [sic] law's impacting his personal belief system, he needs to look at being able to compromise."'100

Commissioner \#2:

Freedom of religion and religion has been used to justify all kinds of discrimination throughout history, whether it be slavery, whether it be the holocaust, whether it be-I mean, we-we can list hundreds of situations where freedom of religion has been used to justify discrimination. And to me it is one of the most despicable pieces of rhetoric that people can use to-to use their religion to hurt others. ${ }^{101}$

In contrast to the Court's treatment of the President's travel ban statements, Justice Kennedy (with the concurrence of six of his eight colleagues) deemed these remarks to provide evidence of

97. Id. at 1726-27.

98. Id. at 1727 (quoting Mullins v. Masterpiece Cakeshop, Inc., 370 P.3d 272, 289 (Colo. App. 2015)).

99. Id. at 1729 (citation omitted).

100. Id. (citation omitted).

101. Id. (citation omitted). 
such a "clear and impermissible hostility"102 toward religion as to infuse the entire proceeding against the baker with sufficient antireligious bias to require its invalidation. ${ }^{103}$ In dissent, Justice Ginsburg observed that the two (out of seven) Commissioners' comments should not be taken to overcome the neutral application of a salutary anti-discrimination statute. ${ }^{104}$ But no matter; the smoking gun had been uncovered. The message the Court sends by searching it out is that when it comes to discrimination, the action taken by government may count for less than even marginally questionable remarks of any officer involved in that action. Contrary to Professor Hellman's admonition, it may be the "thought that counts," 105 unless, apparently, the thinker is President Trump.

\section{The Search for Racial Antagonism (or Animus)}

The final, and perhaps most important, part of Korematsu's enduring Equal Protection legacy grows out of Justice Black's identification of "racial antagonism" as the chief evil both expressed and effected by racially discriminatory measures. ${ }^{106}$ Racially antagonistic laws, never permissible for Justice Black, are to be sharply distinguished from those that serve a "[p]ressing public necessity." 107 The problem with this distinction is that from a perspective of white supremacy, a measure that is identified as prompted by a compelling (or even legitimate) public purpose cannot, by definition, also be racially antagonistic. Recall Plessy $v$. Ferguson: Once racial segregation in public transportation is legitimized as "promot[ing] [the people's] comfort, and the preservation of the public peace and good order," 108 any inference of antagonism may be drawn "solely because the colored race chooses to put that construction upon it." 109 So long as it is used as a proxy, as opposed to an instrument of purposeless animus, race may be freely deployed by public authorities, unrestrained by the Equal Protection Guarantee.

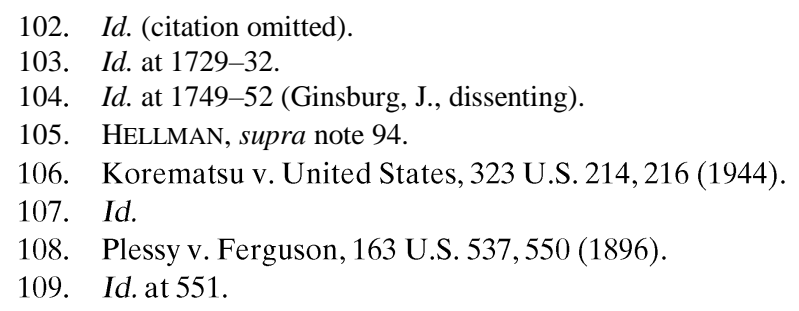


Despite this (too) easy escape hatch, the language of antagonism, or animus, can obviously be useful in challenging measures as invidiously discriminatory. No one can plausibly deny that many Americans harbor identity-based animus toward other human beings, and, sometimes, as President Trump's travel ban remarks show, policymakers openly acknowledge the influence of animus on their decisions. The Supreme Court has relied on its identification of legislative animus to greatly beneficial effect in the series of decisions over the past two decades invalidating state and federal statutes that discriminate against gay and lesbian people. ${ }^{110}$ The Court's opinions in these cases, all written by Justice Kennedy, rely heavily on the government's inability to offer a plausible purpose for the challenged measures beyond "animosity toward the class of persons affected." 111 As the first of these opinions put it,

[L]aws... often can be explained by reference to legitimate public policies which justify the incidental disadvantages they impose on certain persons.... We cannot say that Amendment 2 is directed to any identifiable legitimate purpose or discrete objective. It is a status-based enactment divorced from any factual context from which we could discern a relationship to legitimate state interests; it is a classification of persons undertaken for its own sake, something the Equal Protection Clause does not permit.... A State cannot so deem a class of persons a stranger to its laws. ${ }^{112}$

The telling passage here is that "a classification of persons undertaken for its own sake" cannot ever stand. The reason is that such a classification is not used as a proxy for any identifiable public purpose. ${ }^{113}$ Similarly, in the cases that followed, culminating in the Court's protection of same sex marriage in $2015,{ }^{114}$ there was similarly no proxy for which discrimination against gays and lesbians could stand, only hatred. From United States v. Windsor, invalidating the federal Defense of Marriage Act,

DOMA seeks to injure the very class New York seeks to protect.... In determining whether a law is motived by an

110. See generally Obergefell v. Hodges, 135 S. Ct. 2584 (2015); United States v. Windsor, 570 U.S. 744 (2013); Lawrence v. Texas, 539 U.S. 558 (2003). See also Romer v. Evans, 517 U.S. 620, 635 (1996).

111. Romer, 517 U.S. at 634.

112. Id. at 635 .

113. Id.

114. See generally Obergefell, 135 S. Ct. 2584. 
improper animus or purpose, "[d]iscriminations of an unusual character" especially require careful consideration.... [There] is strong evidence of a law having the purpose and effect of disapproval of that class ... to impose a disadvantage, a separate status, and so a stigma upon all who enter into same-sex marriages. ${ }^{115}$

Until they were struck down by the Supreme Court, laws that discriminated against gays and lesbians-just because they were gays and lesbians-were among the few contemporary official measures that descended to the abysmal McCleskey/Feeney standard. They were imposed precisely because of the harm they inflicted and were thus expressions and instruments of gratuitous homophobia. But what if the federal and state governments that enacted and enforced these measures had been able to advance a plausible legitimate policy goal for any of them, a goal for which LGBTQ status could serve as a proxy? Would the Court still have been willing to strike them as animus based? Or would the legitimate policy have supplanted any possibility of a hateful motive, as it did for "racial antagonism" in Korematsu?

The most recent of the Court's decisions vindicating the rights of gays and lesbians to equal treatment, Obergefell v. Hodges, ${ }^{116}$ offers some indication that these rights do not depend solely on the justices' unwillingness to sustain measures they see as based on naked antagonism. Justice Kennedy's opinion in Obergefell, invalidating state prohibitions on same-sex marriage, employs what, at first blush, seems only a slight linguistic variation on the theme of impermissible animus:

Especially against a long history of disapproval of their relationships, this denial to same-sex couples of the right to marry works a grave and continuing harm. The imposition of this disability on gays and lesbians serves to disrespect and subordinate them. ${ }^{117}$

115. Windsor, 570 U.S. at 769-70 (citation omitted).

116. Obergefell, $135 \mathrm{~S}$. Ct. at 2584 . The Court's protection of the right of gay and lesbian people to marry draws substantially on its 1966 decision in Loving $v$. Virginia, invalidating state laws banning marriage between persons of different races. Significantly for the arguments advanced here, Chief Justice Warren's opinion for the Court in Loving described these "measures [as] designed to maintain White Supremacy," rather than as an expression of racial antagonism. Loving v. Virginia, 388 U.S. 1, 11 (1967).

117. Obergefell, 135 S. Ct. at 2604 (emphasis added). 
Subordination, as we have seen, is not the same as hatred. To subordinate is to treat someone as of lesser moral worth, or as Professor Reva Siegel has argued, to enforce the inferior social status of a historically oppressed group. ${ }^{118}$ It is possible, as our racial history shows, to subordinate a group of people, in this sense, without ever acknowledging any animus toward or bias against them. And if a measure can be immunized against animus by a legitimating policy goal for which group membership serves as a proxy, this cleansing process does not so easily excuse measures which enforce subordination. The comparison breaks down because the question of whether a measure subordinates turns on far more than whether it arguably serves a legitimate interest. Racial antagonism, or animus, is fundamentally a psychological phenomenon. Subordination, on the other hand, is social and political. Identifying racial subordination requires examination of a measure's impact on a subordinated group's political, social, and economic standing, on whether the measure seeks to remedy present or past discrimination against a subordinated group, and, perhaps above all, on the political context from which the measure emerged and/or is enforced. ${ }^{119}$ Measures which subordinate members of a particular group cannot, therefore, be susceptible of validation by the mere invocation of a permissible aim for which such group membership is used as a proxy. From an anti-white supremacist perspective, abolition of the racial subordination that was essential to the maintenance of slavery, and thus to the original Constitution, thus provides a more convincing explanation for the Amendments that constituted the Second Founding than does either the elimination of formal racial classifications or the prevention of racial antagonism. ${ }^{120}$

\section{TWO RECENT EXAMPLES OF KOREMATSU'S ENDURING INFLUENCE}

The argument that the Second Founding redeemed the original Constitution by rescinding its compact with white supremacy depends on the capacity of the post-Civil War Amendments to bring about racial equality. The alternative account advanced here,

118. See Siegel, supra note 56 at $1472-73$.

119. See Siegel, supra note 56.

120. Id.; see Hellman, supra note 94. Professor Hellman convincingly shows that whether a measure demeans a person or a social group rarely, if ever, turns on the animus of the measure's authors toward that group. 
by contrast, suggests that the Supreme Court's adoption of Korematsu's analytical categories-formalism, obliviousness to the ubiquity of societal discrimination, and a search for overt expression of racial animus-as the crucial markers of prohibited discrimination has substantially undermined that capacity. Two contemporary cases, one an influential Supreme Court decision about Civil Procedure, the other a notable recent circuit court examination of voting rights, illuminate the parlous state of racial equality under the Constitution in the shadow of Korematsu.

\section{A. Iqbal}

The first of these cases is the Supreme Court's 2009 decision in Ashcroft v. Iqbal, ${ }^{121}$ a case that is nominally not about the Constitution at all. Iqbal is known mainly for its reinterpretation of the pleading requirements of Rule 8 of the Federal Rules of Civil Procedure. ${ }^{122}$ The decision revived the hard, but also hard to define, distinction between conclusory and factual allegations that characterized nineteenth and early twentieth century code pleading, ${ }^{123}$ and limited the assumption of truth, for Rule 12(b)(6) dismissal purposes, only to those factual allegations which are deemed to "plausibly" point toward a defendant's liability. ${ }^{124}$

But the Iqbal opinion also addressed the showing necessary to make out a prima facie case of invidious discrimination under the Equal Protection Guarantee, in Iqbal discrimination based on the suspect categories of national origin and religion. The plaintiffs in Iqbal were immigrants from Arab and/ or Muslim majority nations who had been detained in federal custody in the aftermath of the September 11, 2001 attacks. They alleged that under policies designed by Attorney General John Ashcroft and FBI Director Robert Mueller, they were subjected to extremely harsh and punitive conditions of confinement because of their religion and national origin. ${ }^{125}$

The plaintiffs could not point to a formal written policy issued by Ashcroft and Mueller which directed their subordinates to impose these conditions on a discriminatory basis. They alleged,

121. Ashcroft v. Iqbal, 556 U.S. 662, 676-77 (2009).

122. Id. at $678-81$.

123. Id. at $678-79$.

124. Id. at 696.

125. Id. at 666. 
instead, that Ashcroft and Mueller's exclusive focus on persons of Arab and Muslim backgrounds betrayed an unconstitutionally invidious purpose. The defendants did not deny that their policy overwhelmingly affected Arab and Muslim immigrants, ${ }^{126}$ and there is no indication from the record in the case that any immigrants from non-Arab/Muslim backgrounds were subjected to harsh treatment. Nevertheless, the Iqbal majority held that the plaintiffs did not state a plausible claim of prohibited discrimination. ${ }^{127}$

The Iqbal majority opinion is noteworthy for its application of the Korematsu categories examined here-formalism, the relevance (or not) of societal discrimination, and antagonism (or animus) as the test for unconstitutional discrimination. First, despite the resemblance of the Ashcroft/Mueller policy to the military implementation of President Roosevelt's Executive Order in Korematsu, the absence of a formal classification based on religion and/or national origin meant that the Court viewed the plaintiffs' claim as a challenge to a formally neutral policy attacked for its alleged purpose and impact. ${ }^{128}$ The possibility of analogizing the case to Yick Wo, and applying strict scrutiny to such a policy because it was enforced in extraordinarily discriminatory fashion, apparently never occurred to the Iqbal majority.

Second, despite conceding the Ashcroft/Mueller policy's exceptionally disparate impact on Arabs and Muslims, the majority found that impact to be entirely irrelevant because it was not accompanied by a plausible allegation of discriminatory purpose. ${ }^{129}$ In reaching this conclusion, the majority opinion did not acknowledge the possibility that Ashcroft and Mueller's policy was established within a context of significant history of societal discrimination against Arabs and Muslims, or, more important, an upsurge in such discrimination and popular hatred in the wake of the September 11th attacks.

Finally, the Iqbal majority apparently viewed Ashcroft and Mueller's alleged use of the plaintiffs' Arab/Muslim background as a proxy for suspicion of terrorism as precluding any plausible possibility that their imposition of harsh conditions of detention was motivated by status-based animus or antagonism. On this

126. Id. at 686 .

127. Id. at 666 .

128. Id. at 667.

129. Id. at $681-82$. 
point, the opinion first recited the McCleskey nostrum that

purposeful discrimination requires more than "intent as volition or intent as awareness of consequences." It instead involves a decision maker's undertaking a course of action "because of, not merely in spite of, [the action's] adverse effects upon an identifiable group." It follows that, to state a claim... [a plaintiff] must plead sufficient factual matter to show that [defendant] adopted and implemented the detention policies at issue not for a neutral, investigative reason but for the purpose of discriminating on account of race, religion, or national origin. ${ }^{130}$

The burden a plaintiff must meet is thus to plea and prove discrimination for the sake of discrimination, i.e. gratuitous animus. If deployed as a proxy for a neutral policy, the use of race, religion, or national origin is apparently permissible, at least so long as that use is not formally memorialized in writing.

For the Iqbal majority, the rationality of the plaintiff's Arab/ Muslim background as de facto a proxy for terrorism was equally obvious:

The September 11 attacks were perpetrated by 19 Arab Muslim hijackers who counted themselves members in good standing of al Qaeda, an Islamic fundamentalist group. Al Qaeda was headed by another Arab Muslim-Osama bin Laden-and composed in large part of his Arab Muslim disciples. It should come as no surprise that a legitimate policy directing law enforcement to arrest and detain individuals because of their suspected link to the attacks would produce a disparate, incidental impact on Arab Muslims, even though the purpose of the policy was to target neither Arabs nor Muslims.... [T]he arrests Mueller oversaw were likely lawful and justified by his nondiscriminatory intent to detain aliens who were illegally present in the United States and who had potential connections to those who committed terrorist acts. As between that "obvious alternative explanation" for the arrests, and the purposeful, invidious discrimination respondent asks us to infer, discrimination is not a plausible conclusion. ${ }^{131}$

To characterize the impact of Ashcroft and Mueller's policy on Arab and Muslim immigrants as merely "incidental" is as generous

130. Id. at 676-77 (first alteration in original) (citations omitted).

131. Id. at 682 (citation omitted). 
to the policy's authors as it is self-serving to the Iqbal majority's rationale. Nevertheless, the impact of that rationale is plain: the presence of a neutral legitimating ultimate goal-the prevention of terrorism-rules out any possibility of discriminatory animus, just as the pressing public necessity of preventing espionage and sabotage ruled out any possibility of racial antagonism in Korematsu. In neither case was the possibility that the challenged measure might nonetheless affect the subordination of Arabs, Muslims, or of Japanese Americans, even considered.

\section{B. North Carolina NAACP}

The second case, the 2016 decision of the U.S. Court of Appeals for the Fourth Circuit in North Carolina State Conference of NAACP $v$. McCrory ${ }^{132}$ is, for now at least, more promising for the Second Founding argument. The case presented a challenge by North Carolina's African American voters to a measure which repealed or amended various provisions of North Carolina's election law which had facilitated voting. ${ }^{133}$ The affected measures-early voting, same day registration, and provisional out of precinct voting-were fruits of the Civil Rights Movement, enacted in the shadow of North Carolina's long and effective effort to suppress black voting during the era of Jim Crow. The plaintiffs alleged that by eliminating these voting aids, with full knowledge of white and African American voters' respective use of each of them, and by simultaneously imposing a new requirement that voters present photo identification at the polls in order to cast ballots, the repeal statute discriminated against African Americans in violation of the Equal Protection Guarantee. ${ }^{134}$

The challenged North Carolina statute contained no formal classification based on race. Moreover, it purported to pursue a neutral, non-racial goal-the prevention of voter fraud. Nevertheless, a panel of the Fourth Circuit enjoined its enforcement on the ground that it had the purpose and effect of thwarting the voting rights of African Americans on the basis of their race. ${ }^{135}$ The statute's new voting restrictions, the court's

132. See generally N.C. State Conference of NAACP v. McCrory, 831 F.3d 204 (4th Cir. 2016).

133. Id. at 214.

134. Id. at 219.

135. Id. at 239-42. 
opinion said, "target[ed] African Americans with almost surgical precision." 136

Significantly, the Fourth Circuit panel also found that the North Carolina Legislature was not, and need not have been, motivated by racial animus in order to have acted unconstitutionally. ${ }^{137}$ Instead, the Court found, the Republicancontrolled legislature sought to curtail voting by African Americans because of the (accurate) belief that they tended to vote for Democrats, another neutral, non-racial reason. ${ }^{138}$ The North Carolina NAACP Court departed from the Supreme Court's approach in Ashcroft v. Iqbal in two important respects. First, it did not demand proof of gratuitous race hatred, discrimination for the sake of discrimination, in order to hold that a formally race neutral measure was enacted for a discriminatory purpose. Second, in part because of North Carolina's ample history of suppression of voting by African Americans, the use of race as a proxy for the attainment of legitimate (preventing voter fraud), or at least permissible (denying votes to Democrats), goal was a Constitutional violation, not the merely incidental consequence of a race-neutral policy choice.

The Fourth Circuit panel opinion in North Carolina NAACP thus explicitly abandoned all three Korematsu analytical categories: It moved beyond a purely formal identification of discrimination; it embraced the significance of past and present societal discrimination against African Americans as an evaluative tool; and it ascribed a racially discriminatory purpose to a statute it found to have been enacted without racial animus.

The procedural path of the North Carolina NAACP litigation was tortuous. In the end, the Supreme Court declined to review the Fourth Circuit's final judgment. ${ }^{139}$ But along the way, a preliminary injunction ordered by that court was affirmed by an equally divided Court shortly after Justice Scalia's death. ${ }^{140}$ The equal division meant that the Justices issued no opinions. But it also meant that there were then four votes (obviously not counting

136. Id. at 214 .

137. Id. at 233 .

138. Id. at 225-26. (2017).

139. North Carolina v. N.C. State Conference of NAACP, 137 S. Ct. 1399, 1339

140. North Carolina v. N.C. State Conference of NAACP, 137 S. Ct. 27, 27-28 (2016). 
that of Justice Gorsuch) to overturn the Fourth Circuit's approach to Equal Protection challenges based on alleged racially discriminatory purpose and impact. If so, there may now be five Justices who are prepared to give their blessing even to measures that openly "target African Americans with almost surgical precision," "141 so long as their authors deploy that targeting as a proxy for a facially legitimate purpose. Such a thorough readoption of Korematsu's methodology would almost completely eviscerate the equal protection guarantee. It would be a shield against formal race classifications, regardless of their aim, but would reach no further. Facially neutral measures, even when they openly targeted racial minorities, would be immune from attack unless shown to be based on gratuitous hatred.

\section{KOREMATSU'S EMPTY OVERRULING}

In Trump v. Hawaii, decided at the close of the Supreme Court's 2017-18 term, Chief Justice Roberts announced, on behalf of a 5-4 majority of the justices, that the Court's validation of the "morally repugnant" Korematsu exclusion order was overruled. ${ }^{142}$ Apparently prompted by Justice Sotomayor's comparison of President Trump's travel ban to the mandatory evacuation of persons of Japanese national origin, the Chief Justice replied as follows:

The dissent's reference to Korematsu, however, affords this Court the opportunity to make express what is already obvious: Korematsu was gravely wrong the day it was decided, has been overruled in the court of history, and - to be clear- 'has no place in law under the Constitution' - . . (Jackson J. dissenting). ${ }^{143}$

By formally burying Korematsu, the Court has finally ratified the now nearly universal consensus that the mandatory evacuation of persons of Japanese ancestry was unconstitutional, and that the Court ought not to have sustained it. This essay, which has assumed the correctness of that consensus, has argued that Korematsu nevertheless continues to exert a deep and malign influence over our understanding of the equal protection guarantee, to the detriment of our aspiration to racial equality. It is fair, then, to ask whether the Court's overruling of the decision

141. McCrory, 831 F.3d. at 214.

142. Trump v. Hawaii, 138 S. Ct. 2392, 2423 (2018).

143. Id. 
and, especially, Chief Justice Roberts' observations that Korematsu was both morally repugnant and gravely wrong the day it was decided also to signal a rejection of that influence, or at least an acknowledgement that is has been regrettable.

Any answer to this question must begin by identifying what it is about Korematsu that has now earned the Chief Justice's emphatic repudiation. And in turn, the most immediate source of insight into his understanding of the wrong of Korematsu is to compare it with his own opinion in Trump v. Hawaii. Obviously, Chief Justice Roberts believes that his decision to sustain the President's ban on most non-citizens' travel into the United States from many Muslim majority countries is consistent with his rejection of Korematsu.

The travel ban was challenged as discriminatory on the basis of religion in violation of the Establishment Clause of the First Amendment. The language of the ban was racially neutral with respect to religion. The challengers argued nevertheless that its primary purpose was to implement a policy of religious discrimination against Muslims. They claimed, as we have seen, that this purpose was evidenced by a long series of statements by candidate, then President, Trump demonstrating dislike, disapproval, and fear of Islam and its adherents. By contrast, the military evacuation order at issue in Korematsu, despite its formally neutral aspects (described above), was deemed by Chief Justice Roberts to have been affected "solely and explicitly on the basis of race." $" 144$

Over the objections of dissenting Justices Sotomayor and Ginsburg, the Chief Justice evaluated the travel ban under a rational basis standard of judicial scrutiny as opposed to the strict scrutiny standard announced and (ostensibly) applied in Korematsu. Still, in applying rational basis review, Roberts was prepared to look beyond the ban's facial neutrality in order to assure that it resulted from a justification independent of unconstitutional discrimination on the basis of religion. ${ }^{145}$ The test for identifying such an independent justification was whether the ban had any purpose other than a "bare... desire to harm a politically unpopular group." ${ }^{146}$ Relying on Romer v. Evans, the first of the court's decisions protecting LGBTQ persons from

144. Id.

145. Id. at 2426

146. Id. at 2420 (citation and quotations omitted). 
facially discriminatory laws, the Chief Justice emphasized that even a neutral measure would be unconstitutionally discriminatory if it was "inexplicable by anything but animus," 147 or as Justice Black put it in his parallel discussion in Korematsu, "antagonism."

The record in Trump $v$. Hawaii was replete with evidence of anti-Muslim animus, most of it directly from the President's mouth, as a driving motivation behind all three iterations of the travel ban. Justice Sotomayor's dissent tallies six pages of vitriolic bigotry, ${ }^{148}$ none of it contested by Chief Justice Roberts. Why didn't this uncontroverted record of religious antagonism doom the travel ban, or at least weigh significantly against its constitutionality? For the same reason that Justice Black ruled out racial antagonism as playing any role in evaluating the evacuation order in Korematsu. In both cases, the explanatory force of animus, blatant in Trump $v$. Hawaii, and persuasively demonstrated in Korematsu, was nullified by the government's invocation of national security. Recall Justice Black: the military judgment that "exclusion of the whole group was a military imperative answers the contention that the exclusion was in the nature of group punishment based on antagonism to those of Japanese origin." 149 Compare this with Chief Justice Roberts in Trump v. Hawaii: "It cannot be said that ... the policy is 'inexplicable by anything but animus.'...[B]ecause there is persuasive evidence that the entry suspension has a legitimate grounding in national security concerns, quite apart from any religious hostility, we must accept that independent justification." 150

So what can we conclude about why Chief Justice Roberts so forcefully overruled Korematsu while sustaining President Trump's travel ban? The cases are quite similar. The Court's opinions both purport to condemn invidious discrimination and to apply a standard of scrutiny that is sufficiently rigorous to ferret it out. Both see racial and religious antagonism or animus as the evil to be prevented by judicial scrutiny. Both see an alternative explanation for a discriminatory law or policy as sufficient to nullify such antagonism (at least if its source is the President of the United States rather than a state civil rights commissioner). And, as Justice Sotomayor points out in her Trump v. Hawaii dissent, both

147. Id.

148. See id. at 2433-48 (Sotomayor, J., dissenting).

149. Korematsu v. United States, 323 U.S. 214, 216 (1944).

150. Trump,138 S. Ct. at 2420-21. 
opinions are equally indifferent to the likelihood that the Presidential policies they review are rooted in deep-seated societal prejudice against a racial or religious minority. ${ }^{151}$

What remains, of course, is the difference with which we began this comparison. President Trump's travel ban does not make a formal religious classification. President Roosevelt's executive order in Korematsu did not either. But General Dewitt's evacuation order implementation was facially, not just in purpose and impact, directed at persons of Japanese ancestry.

So, for Roberts, echoing his opinion in Parents Involved, ${ }^{152}$ form is everything. His belated outrage at the Japanese evacuation is not because of its racial antagonism-Trump's travel ban is at least as antagonistic, overtly probably more-and not because its national security rationale was weak - the national security bona fides of the travel ban are, as Justice Sotomayor shows, much weaker than those in Korematsu. Roberts' outrage is entirely owing to the fact that the Korematsu military order named its targets openly.

In this sense, Chief Justice Roberts' overruling of Korematsu in Trump v. Hawaii is itself purely formal. In practice, his opinion reinforces Korematsu's unfortunate equal protection legacy. By focusing almost exclusively on facially invidious classifications, by ignoring ubiquitous societal discrimination against racial and religious minorities, and by searching after animus as opposed to subordination as crucial wrong of discrimination, the Chief Justice's Trump v. Hawaii opinion entrenches Korematsu's impact on our law. In light of what he has actually done, Chief Justice Roberts' denunciation of Korematsu as "morally repugnant" proves far too much. He might have said, more accurately, "Korematsu is dead. Long live Korematsu."

\section{CONCLUSION: A BETTER WAY FORWARD?}

The lasting influence of Korematsu has made the path toward racial redemption by way of the so-called Second Founding a long and arduous one. The obstacles set along this path are considerable-racially discriminatory policies that harm African Americans and other racial minorities are likely unconstitutional

151. See id. at 2433-48 (Sotomayor, J. dissenting). (2007).

152. Parents Involved in Cmty. Schs. v. Seattle Sch. Dist., 551 U.S. 701, 745-48 
only if the policies do so formally and explicitly, which today is very unlikely. On the other hand, racially remedial measures, which are likely to be formal and explicit precisely because of their remedial aims, are often struck down for that very reason. Measures that are formally neutral but disparately damage the lives of African Americans and other minorities as compared to whites will be evaluated by the courts with great deference to the governmental bodies who adopt them. Only rarely will these courts give weight to either our past and present societal structures of discrimination or the often unconscious, but no less real, white supremacist assumptions that perpetuate these structures. Instead, judicial review of formally neutral measures will seek to ferret out an elusive racial animus or antagonism that is rarely expressed and is thus nearly always nullified if race is used as a proxy for the pursuit of other goals. Whether a measure subordinates a racial group, on the other hand, is rarely a consideration.

These doctrinal barriers are indeed formidable. But, perhaps we need not be without hope. Constitutional doctrines, as we have seen many times throughout our history, are rarely permanent. And sometimes, as the success of the gay and lesbian movement for legal equality has taught us, ancient doctrines can be unraveled and replaced by new and better ones with considerable speed. ${ }^{153}$ Though the Constitutional law of race is, as we have seen, deeply entrenched, a different doctrinal approach to that law is available, even if the results its adoption might yield are unpredictable. This alternative approach is exemplified by Justice Ginsburg's opinion for the Court in United States v. Virginia. ${ }^{154}$ That opinion famously invalidated the Virginia Military Institute's ban on the admission of female students as unconstitutional discrimination on the basis of sex. ${ }^{155}$ But Justice Ginsburg also sought to ensure that requiring VMI to admit women would not, or at least would not automatically or reflexively, provide an argument for the demise of single-sex colleges for women which barred the enrollment of men. Accordingly, Justice Ginsburg reminded us that not all gender classifications are the same. Some gender classifications, those that "create or perpetuate the legal, social, and economic inferiority of

153. See generally Obergefell v. Hodges, 135 S. Ct. 2584 (2015).

154. See generally United States v. Virginia, 518 U.S. 515 (1996).

155. See generally id. 
women," may never be used. ${ }^{156}$ But there are others, the admission policies of women's colleges among them, that are employed "to dissipate rather than perpetuate traditional gender classifications." ${ }^{57}$ There is perhaps a paradox on the surface of this observation: How can a gender classification be used to dissipate gender classifications? But the resolution is obvious once we recognize that measures aimed at remedying the subordination of a disfavored group are entirely different from those which enforce that subordination. The form taken by either sort of measurethat is, whether it explicitly classifies on this basis of group membership or not-is less important than what it actually does.

If we could import Justice Ginsburg's approach to unconstitutional sex discrimination over into our law of race discrimination, and especially if we could extend that approach to formally neutral measures as well, we might significantly improve the chances that the post-Civil War Amendments can achieve their redemptive promise of racial equality. This rethinking would enable, even direct, our courts to focus explicitly on whether challenged laws "create or perpetuate the legal, social, and economic inferiority" 158 of African Americans or other racial minorities in order to adjudicate their constitutionality. Such a focus would in turn require courts to consider the remedial (or subordinating) goals of challenged measures, their impact on the lives and social standing of racial minorities, the effects of past and present societal discrimination in their adoption and execution, and the possibility that they were influenced by unconscious racial denigration growing out of our common and tragic legacy of white supremacy. Whether a challenged measure formally classified people on the basis of race would not be irrelevant. But it would be just one factor among many rather than the sine qua non of unconstitutional discrimination. Notwithstanding Chief Justice Roberts' admonition in Parents Involved, it is not always true that "the way to stop discrimination on the basis of race is to stop discriminating on the basis of race."159

To acknowledge the obvious, none of this would be easy in practice. Not every law or policy with an adverse impact on racial

156. Id. at 534 .

157. Id. at 534 n.7 (quoting Brief for Twenty-Six Private Women's Colleges as Amici Curiae Supporting Petitioner (1995) (WL 702837)).

158. Id. at 534 .

159. Parents Involved in Cmty. Schs. v. Seattle Sch. Dist., 551 U.S. 701, 748 (2007). 
minorities would be unconstitutional. Not every purportedly remedial measure would be sustained. The outcomes of challenges based on a law or policy's alleged discrimination would, for a time at least, and maybe indefinitely, be considerably less predictable than they are now. They would require, to borrow from Hamilton, judgment of a much more nuanced sort. ${ }^{160}$ To condemn racial subordination will not provide a ready algorithm for identifying it.

And there is a deeper problem. By asking judges to reject an almost purely formal approach to racial discrimination in favor of one that pursues a more substantive vision of racial justice, we may be demanding more of them than they can deliver. First, and most crucially, our current formal approach to race jeopardizes racially remedial measures above all others because they are likely to be open about their aims. It also almost completely ignores the disparate racial impact of our public policies, one of the most enduring features of American society. This state of affairs is likely to draw little objection from whites, many of whom are comfortable in the belief that equality is simply formal equality. A more vigorous judicial commitment to the eradication of racial subordination will lead not only to white discomfort but also to a reduction of unjustified white advantage. Indeed, that is part of the point of racial equality. This is not to suggest that racial justice is a zero-sum game. ${ }^{161}$ But it is to wonder whether our judges, themselves drawn almost by definition from elite backgrounds, are likely for long to pursue or sustain outcomes aimed at fundamentally changing a long-standing and stable, if unjust, racial distribution of social advantages.

Perhaps more vexing is the question whether independent Article III federal judges, even assuming they are less constrained by popular opinion than are elected officials, can or should be trusted with the power to decide which laws "create or perpetuate the legal, social, or economic inferiority" 162 of African Americans and other racial minorities, and which ones, by contrast, "dissipate" such inferiority. Imagine the differences between the likely views of, say, Justices Ginsburg or Sotomayor on this question from those of Justice Alito or Thomas. Are the platonic guardians actually

160. THE FEDERALIST No. 78 (Alexander Hamilton).

161. See generally Derrick Bell, AND We ARE Not SAVED: The Elusive Quest FOR RACIAL JUSTICE (1987).

162. Virginia, 518 U.S. at 534. 
equipped to protect minorities from racial subordination? ${ }^{163}$ With respect to race, then, formalism may not offer much justice, but it does at least afford racial minorities a certain safe harbor from the worst sorts of race-based official, and perhaps even judicial, abuse.

So, a measure of caution about the efficacy of Justice Ginsburg's subtle, flexible, and above all, substantive vision of Constitutional anti-discrimination law is in order. And yet, to surrender to this caution and settle for the inadequate postKorematsu law of race we have wrought is to concede that black lives may matter to the Constitution, just not all that much. If we are to transcend the white supremacist heritage bestowed upon us by the original founders, the heritage of Dred Scott and Plessy, we Americans should act as if we have the courage to demand that the Second Founding live up to its aspiration to end racial subordination in our country. That means insisting that our constitutional law of race at least ask the right questions, no matter how uncertain, unsettling, and painful the answers to these questions are likely to be.

163. LEARNED HAND, THE BILl OF RightS 73 (1958). 